\title{
La justicia y la hechicería en el oriente de Michoacán: el juicio de Juan Rosales en 1732
}

Justice and Witchcraft in Eastern Michoacán: The Trial of Juan Rosales in 1732 Justice et sorcellerie dans le Michoacán oriental: le procès de Juan Rosales en 1732

Quetzalcoatl Tonatiuh Uribe Sánchez

\section{OpenEdition}

\section{Journals}

Edición electrónica

URL: http://journals.openedition.org/rhj/3388

DOI: $10.4000 /$ rhj.3388

ISSN: 0719-4153

Editor

ACTO Editores Ltda

Referencia electrónica

Quetzalcoatl Tonatiuh Uribe Sánchez, «La justicia y la hechicería en el oriente de Michoacán: el juicio de Juan Rosales en 1732 », Revista Historia y Justicia [En línea], 11 | 2018, Publicado el 01 octubre 2018, consultado el 27 julio 2020. URL : http://journals.openedition.org/rhj/3388 ; DOI : https:// doi.org/10.4000/rhj.3388

Este documento fue generado automáticamente el 27 julio 2020.

Revista Historia y Justicia 


\section{La justicia y la hechicería en el oriente de Michoacán: el juicio de Juan Rosales en 1732}

Justice and Witchcraft in Eastern Michoacán: The Trial of Juan Rosales in 1732

Justice et sorcellerie dans le Michoacán oriental: le procès de Juan Rosales en 1732

Quetzalcoatl Tonatiuh Uribe Sánchez

\section{NOTA DEL EDITOR}

Recibido: 12 de julio de 2018 / Aceptado: 30 de septiembre de 2018

\section{El Tribunal Ordinario y la aplicación de justicia en contra de los indios}

1 La impartición y aplicación de justicia en contra de indios corresponde a una separación jurídica y jurisdiccional de éstos con el resto de la población novohispana, dicha desunión se ve reflejada con la instauración el Tribunal Ordinario y el Santo oficio. La situación del indio debía de ser definida con la intención de establecer la función social de las instituciones españolas sobre los nuevos colonizados, a razón de ello se plantearon posturas con el fin de cobijar al indio y reconocerlo como vasallo del rey. Aceptar la humanidad de los nativos americanos permitió que se les inculcara el evangelio y posteriormente establecer una serie de normativas jurídicas que permitieran el uso "correcto" de las leyes cuando éstos transgredían el orden civil y religioso ${ }^{1}$.

2 A los indios se les categorizó como personas miserables, personas sin razón pero con alma, neófitos en la fe y personas tímidas, esta condición jurídica apuntan a una 
separación jurisdiccional a la hora de impartir y aplicar la justicia eclesiástica pues como bien se ha investigado la personalidad de miserable ofrecía diversas interpretaciones como aquellos seres en desventaja que debían ser protegidos ${ }^{2}$. La personalidad de miserable permitía a los indios recibir un trato diferente cuando éstos se enfrentaban a la justicia eclesiástica por delitos contra la fetales como la hechicería, idolatría, adivinación, hechicería y curanderismo, prácticas que estaban muy arraigadas por la sociedad novohispana envueltas en un sistema de aculturación ${ }^{3}$.

En cuanto a la personalidad miserable de los indios, así como su categoría de tímido y neófito en la fe, exigía que los párrocos y sacerdotes como responsables de enseñar, cuidar y conocer a su rebaño debían ser implacables en su trato y su forma de dirigirse a los nativos de tal forma que debían cobijarlos con amor paternal, pedirle a los párrocos que trataran dulcemente a los indios tenía como finalidad que los naturales se acercaran sin temor a recibir los sacramentos y pospuesto llevar acabo el adoctrinamiento cristiano y reconocer cuando un nativo aún hacía ceremonias de idolatría, hechicería, curanderismo, adivinación etc. Podemos inducir que el paternalismo religioso estipulado por los humanistas y reflejado en los estatutos del Tercer Concilio Provincial Mexicano legitimaba la conquista y evangelización de España sobre los territorios de indios en América.

4 A los naturales se les consideró como personas sin razón pero con alma, esto permitía que la justicia fuese "piadosa" cuando a los naturales se les encontraba culpables de haber cometido algún crimen contra la fe, en ese sentido, debemos inclinarnos hacía el análisis del Tercer Concilio Provincial Mexicano pues en ese sínodo se erogaron diversos estatutos del cómo se debía juzgar a los indios cuando se encontraban en un juicio religioso. $\mathrm{Al}$ ser considerados como personas en desventaja se le pedía a los jueces que pusieran especial atención sobre quiénes acusaban y testificaban en contra de los indios, con la finalidad de velar por su alma y cuidar de su crédito como buenos cristianos.

5 Con el propósito de garantizar los derechos de los indios en la aplicación de justicia Felipe II instauró el Tribunal Ordinario en 1569, el objetivo de esta institución era proporcionar la justicia en contra de los indios con base en las categorías ya expuestas y al ser neófitos en la fe los castigos aplicados eran totalmente distintos a los que recibían los viejos cristianos ${ }^{4}$. Posteriormente en 1571 se introdujo en América el Tribunal de la Santa Inquisición la cual no tuvo jurisdicción sobre los indios en materia de fe. Por último, en 1585, con la celebración del III Concilio Provincial Mexicano, se complementaron las normas que dotaban de una capacidad jurídica particular a los indios 5 .

El Tribunal Ordinario estaba constituido por el obispo, seguido de un provisor y los jueces eclesiásticos. Había jueces auxiliares los cuales eran designados por el obispo o provisor para atender casos relacionados con asuntos de fe. Al celebrarse un juicio, un notario eclesiástico acompañaba al juez en sus actos, para dar legalidad a las denuncias, testimonios recibidos durante los interrogatorios y el resto del proceso. Otras atribuciones de esta institución eran las de velar por la aplicación de la doctrina y el resguardo de sus cánones morales. La separación racial en torno a la justicia debió de facilitar los juicios. Sin embargo, el juez debía ser precavido pues no faltaron los casos de quienes quisieron hacerse pasar por indios con la finalidad de recibir un trato especial o más benévolo lo que nos permite inducir el conocimiento que tenía la población sobre la especial impartición y aplicación de justicia hacia los naturales ${ }^{6}$. 
7 El fuero mixto es un concepto aplicado para la Nueva España basado en los crímenes que alteraban el orden civil y religioso. Se componía de un foro interno que estaba relacionado a la curia del cielo, es decir a la conciencia y el foro externo que se vinculó a lo contencioso, alegado y probado. Un crimen de fe como lo fue hechicería o curanderismo se trataba como fuero mixto pues alteraba el orden civil y divino ${ }^{7}$. Ante una denuncia de fuero mixto el juez debía reunir las pruebas basadas en los testimonios de los testigos, en su mayoría orales, esto con la finalidad de poder emitir un castigo ${ }^{8}$.

El descargo de conciencia, era el precepto bajo el cual se hacía la denuncia o se establecía un testimonio. El actor era quien denunciaba sobre la existencia de un crimen contra la fe y el juez con su testimonio conocía las causas del posible acto ilícito y procediera a abrir la indagatoria y la recopilación de datos, citara a los testigos y al inculpado a declarar. Los juicios se dividían en ordinarios, conocidos como juicios de fuero eclesiástico o regulares, los cuales eran exclusivos de la jurisdicción de los obispos y los provisores. Los juicios que competían a la Inquisición o fuero secular9.

9 En el caso de un juicio eclesiástico a pesar de que fuera ordinario, poseía un carácter que lo hacía particular, y era precisamente cuando se llevaba a cabo un procedimiento en contra de la fe. Murillo Valverde explicaba esta causa como temporal y espiritual. En los juicios ordinarios se invocaba la protección del indio con aquél trato dulce y benevolente del que hablamos antes, pues al atender las ofensas morales y de fe el juez ordinario no podía recurrir a castigos que no estuvieran sustentados en los estatutos del Tercer Concilio Mexicano:

"Las causas que pertenecen al juicio eclesiástico son de dos clases: una son 'espirituales', las cuales también se llaman 'meramente eclesiásticas'; otras son 'temporales'. 'Espirituales' se dicen las que por su objeto son sagradas y versan acerca de una cosa sagrada. 'Temporales' son las que de por sí tienen un objeto profano, pero son llamadas eclesiásticas, porque se plantean contra una persona eclesiástica, o corresponden al juez eclesiástico por otra razón. Las causas espirituales, o meramente eclesiásticas, aún promovidas entre y contra los laicos, corresponden al juez eclesiástico"10.

10 A los indios acusados y encontrados culpables de superstición no eran mortificados con torturas ni se les aplicaba la pena capital, señalando que un crimen supersticioso tenía un pacto implícito y explicito con el demonio. No obstante, bajo la protección divina y humana encarnada en el rey, cuando era llevado a juicio, el juez quedaba obligado a considerar que éste, quizá de forma involuntaria podía haber sido influenciado o engañado por el demonio ${ }^{11}$. El concepto de "ignorancia invencible" que protegía al indio, iba de la mano con su actuar religioso, pues se consideraba que los naturales eran tan frágiles que bajo malas influencias podía romper el orden moral impuesto y como resultado de esa ignorancia se aferraban a sus creencias supersticiosas y mágicas.

11 El Tribunal de Justicia Ordinario o Provisorato de Indios, al mismo tiempo servía para que los indios fueran presentados ante la ley, también fue la institución a través de la cual los naturales podían defenderse, acusar y encontrar solución a los conflictos que les quejaban y que vinculaban a otros individuos. El Tribunal Ordinario ayudaba a juzgar y penalizar a los indios renuentes a respetar la doctrina, nativos empeñados en mantener sus creencias o prácticas supersticiosas, estas transgresiones contra la fe eran consideradas pecaminosas pues representaban una falta a Dios y el Soberano.

Para obtener el cargo de juez se debía cumplir con algunos requisitos, los cuales eran: haber estudiado derecho canónico, tener una edad de 18 a 26 años, y se dice ordinario porque conocía las causas de los súbditos de la corona y acuden a párroco o juez 
eclesiástico ${ }^{12}$, y al tener conocimiento de la jurisdicción y sus habitantes, se consideraba podía hacer uso del foro de conciencia. El foro de conciencia consistía, en que el juez ordinario, realizara un análisis del razonamiento o estado de conciencia religiosa que tenía el reo, para saber si éste tenía conocimiento de las consecuencias del crimen que cometió o se le acusaba ${ }^{13}$. Sobre la "ignorancia invencible", Murillo Velarde la relacionaba con la costumbre, que se basaba en tener un comportamiento al margen de la doctrina. De no ser así, se consideraba como corruptela, una acción que se realizaba de forma intencionada. Sobre el tema Murillo explicaba lo siguiente:

"Ninguna costumbre puede obtener fuerza de la ley divina o la ley natural. Si no es razonable, no se llama costumbre, sino corruptela, la cual, por tanto debe ser arrancada de raíz [...] el obispo castiga los delitos de los clérigos y de los laicos, que pertenecen al fuero eclesiástico, no sólo con la aplicación de censuras y penas eclesiásticas contra contumaces, sino, también, corporales, de cárcel, galeras y azotes" ${ }^{14}$.

13 A partir de las instrucciones de Murillo Velarde cabe preguntarse: ¿si dentro de las faltas a la fe y la moral, los indios que fueron acusados de hechiceros tenían pleno conocimiento del delito por el que eran incriminados? y ¿sí el proteccionismo y paternalismo con el que los naturales fueron cobijados permitía que las tradiciones y costumbres culturales se siguieran reproduciendo hasta el siglo XVIII? Con base en la cita anterior se presta importancia al conocimiento que los párrocos debían tener sobre sus feligreses, la ley eclesiástica quedó a la interpretación debido a las diversas expresiones culturales que representó la Nueva España, en esa casuística los jueces debían analizar los datos arrojados por los actores y testigos para concluir si efecto había un crimen supersticioso. Pues bien, desde las estructuras del poder colonial, la hechicería era considerada como en Europa, una costumbre herética vinculada a la seducción provocada por el diablo ${ }^{15}$.

En este sentido, la jurisdicción del Tribunal Ordinario, para impartir justicia se organizó de acuerdo a la diócesis. De esa manera el control religioso de los pueblos de indios se distinguía de las normas que se aplicaba a los peninsulares, mestizos, negros y castas ${ }^{16}$. El obispo era el responsable de impartir la justicia ordinaria, conocida como la casuística. Bajo la jurisdicción del obispado, no sólo había que hacer énfasis en la representación territorial, sino que además se podían abarcar varias costumbres nativas a lo largo de las regiones conquistadas por España, por lo cual, hacía que la vigilancia sobre la feligresía de indios quedara también en manos de los curas párrocos a lo largo de los obispados. El Provisorato de Indios fue una institución que ofrecía una de las formas para mantener estrecha vigilancia sobre la población nativa ${ }^{17}$. Bajo ese gobierno religioso se organizó el control de la doctrina. El juez al recibir denuncia sobre un crimen de fe podía solicitar apoyo a los seculares para aprehender al inculpado, confiscar sus bienes si así se determinaba al concluir el juicio y para aplicar el castigo:

"Juez se llama, como el que dicta el derecho al pueblo, es decir, el que decide en derecho, y decidir en derecho es juzgar justamente. Y como juzgar es un deber público, de aquí se sigue que el juez debe tener potestad pública, es decir jurisdicción para conocer y decidir las causas y controversias, y ciertamente ordenadas por el bien de los súbditos, y a esto se reduce el oficio del juez, del que aquí se trata: porque éste no es otra cosa que cierto cargo público para conocer y decidir las cosas controvertidas en un juicio"18.

Juzgar con imparcialidad evocaba a los límites de poder que ejercían los jueces. El papel del juez terminaba una vez que reunidos los elementos de la causa, dictaban sentencia y pronunciaban la pena que debía afligirse al reo, así dejaba salvaguardado el principio 
del justo proceso. La función de los curas párrocos era instruir a sus ovejas en la doctrina, alejarlos de las malas costumbres e introducirlos en el camino de la moral; vigilar que ninguna de las almas que tenía a su cargo abandonara los preceptos religiosos o reincidiera en delitos de crímenes contra la fe.

La función social y religiosa de los párrocos era el cuidado de los indios, protegerlos de las injurias a las cuales podían ser objeto razón por la cual en los juicios los jueces debían prestar atención al crédito del actor y los datos de su denuncia así como analizar la vida cristiana de los testigos. La finalidad de establecer una institución como el Tribunal Ordinario era para erradicar las malas costumbres por medio de juicios y castigos y en esa economía del poder hacerle ver a la población lo vehemente y piadosa que podía ser la Iglesia. La protección del indio se vería reflejada cuando éste no transgrede las normas civiles y morales de la época, al ser buen cristiano los funcionarios eclesiásticos podían velar por su alma así como defenderlos de las falsas acusaciones pues había de por medio un historial como buen religioso. Cuando los naturales se enfrentaban a ante el Tribunal por algún crimen de fe la protección se reflejaría cuando el obispo intercedía por el perdón del transgresor sin embargo cuando se emitía un castigo muy rara vez el obispo intercedía.

Las instituciones a través de sus leyes reflejan la concepción de una realidad moral, religiosa y civil con la finalidad de establecer un orden gubernativo que permita definir lo bueno de lo malo, en ese tenor las actividades supersticiosas atienden a una concepción tradicional en la cual se ve contemplada en el sincretismo religioso que es pernicioso según la percepción de las instituciones cristianas. La protección a la que estaban sujetos los indios partió de la creación de una institución que prestó atención sobre los crímenes supersticiosos que cometían, aplicando la justicia benevolente para la época, esto en comparación del trato que recibían los viejos cristianos ${ }^{19}$.

\subsection{Delitos contra la fe. El pecado y castigo}

Examinadas las funciones de los obispos y jueces eclesiásticos, así como sus ámbitos de jurisdicción y límites, señalaremos aquellas acciones que fueron denominados como crímenes contra la fe. Vigilar y castigar ese tipo de comportamientos fue el modelo que se siguió durante la colonia, como forma de gobierno religioso. El propósito era el de garantizar la paz y la convivencia entre los novohispanos. A lo expuesto anteriormente, la convivencia se podía regir siempre y cuando no se rompiera el orden civil y divino, es decir no se cometiera un delito de fuero mixto, en los cuales se encontraban: la hechicería, el curanderismo, la magia, la adivinación y los encantamientos ${ }^{20}$.

19 En el caso de la hechicería y curanderismo se puede señalar que eran parte de las costumbres culturales más arraigadas en la sociedad novohispana. Las dinámicas e intercambios que en la vida cotidiana se daban entre una población tan heterogénea y diversa como la novohispana hizo posible que la superstición compartida por españoles, indios, esclavos y el resto de las castas se mantuviera. De tal suerte que al definir los castigos por practicar la hechicería y el curanderismo en el Tercer Concilio se indicaba:

"Tampoco acuda nadie a tales hechiceros y encantadores, para valerse de sus maleficios o hechizos pues de lo contrario hará penitencia pública de un día de fiesta, mientras se celebra misa conventual de su parroquia en donde estará de pie con la cabeza descubierta sin capa y descalzo, ceñido de una siga, y con una vela encendida en la mano; y allí se leerá públicamente la sentencia dada contra él; y 
además de esto, si fuere español pagará dos marcos de plata para la fábrica de la iglesia denunciante y obras pías, a ellos, acusando su delito: y el mismo caso podrán también conmutar en otra la pena corporal, según su calidad"21. de ella se podía predecir el futuro y por ello se consideró una actividad herética y contenciosa. A los adivinos también se les consideró que tenían un pacto con el demonio o que éste actuaba a través de ellos, pues el único que podía conocer y decidir sobre el futuro era Dios. Por lo cual las artes mágicas eran otro de los actos en contra de la fe:

“(...) así llamada, como emulación de la divinidad (...) adivinanza querer tomar el poder de Dios para saber las cosas que están por venir; porque los que la ejercen simulan que están llenos de la divinidad, y por lo mismo se llamaban adivinos, es manifestar cosas contingentes ocultas libremente futuras, o de otra manera desconocidas, por un pacto con el demonio, o explicito, por el que se ve se invoca expresamente al demonio, o implícito, como cuando se utiliza algún signo para el conocimiento de las cosas, que es vano de por sí y no tiene con las cosas ocultas ninguna conexión natural, o virtud para tales efectos, ni sobrenatural, por voluntad y revelación de Dios, por disposición u oraciones de la iglesia" ${ }^{24}$.

La magia según Murillo Velarde era aquella que podía causar un mal, utilizada para conseguir el amor, o simplemente para forzar un poder y a través de él obtener alguna sanación:

“(...) que es el arte de obrar cosas admirables, una es natural, otra supersticiosa, la natural es aquella que por causas naturales produce algunos efectos admirables (...) la supersticiosa, es cuando por tales cosas se obran por acción del demonio, invocándolo o expresa o tácitamente, por medio de signos que no tienen ninguna conexión natural con el efecto. Si tiene a dañar a otro, se llama maleficio o hechicería. Alguna vez se hace para conciliar un amor y se llama filtro amatorio, o hechizos"25.

24

De allí que cuando el tribunal tenía que actuar en este tipo de casos, se infringía al cuerpo y las penitencias estaban destinadas a purgar el alma ${ }^{26}$. Los métodos correctivos del cuerpo tenían la finalidad de enseñar a los naturales sobre aquellas conductas que no eran tolerables para la Iglesia ${ }^{27}$. No obstante, el tipo de castigos aplicados a los indios 
tales como los azotes, el encarcelamiento, confiscación de bienes, o la penitencia pública al exhibirlo frente a su comunidad, no debilitaron la fuerza que esas prácticas tenían en el siglo XVIII. La sociedad colonial en su conjunto mantenía un sin fin de creencias provenientes de distintas tradiciones de origen religioso, que se fueron incorporar a las católicas en una especie de mixtura a la que se iba amoldando el pensamiento mágico de los diversos colectivos.

\section{Tuzantla. La diversidad cultural en el oriente del obispado de Michoacán}

Maravatío ${ }^{28}$, se encontraba ubicado en el oriente michoacano y era una región que en esos años, pertenecía al obispado de Michoacán. Para 1732 el obispado abarcaba un amplio territorio que estaba constituido por los actuales estados de Michoacán. San Luis Potosí, Guanajuato y Colima ${ }^{29}$.

Autores como Jesús Teja sugieren que el nombre de Tuzantla proviene del náhuatl y significa lugar "donde abundan las tuzas" ${ }^{30}$. Antes de la llegada de los españoles la región fue habitada por los tarascos, matlazincas y aztecas, lo que desde sus orígenes la hacía una zona excepcional por la diversidad de componentes y riqueza cultural que encerraba en un pequeño microcosmos, variedad lingüística, convivencia racial de una pluralidad de grupos y como lugar de frontera y constante tensión entre los que habitaron ese territorio. Era una franja que limitaba el dominio de los tarascos, de sus enemigos los aztecas. En la región se introdujo el cultivo de la caña de azúcar y comenzaron aparecer los primeros trapiches, que durante los ciclos de corte y molienda de caña, atrajeron a numerosos grupos de trabajadores del interior de la región y de otros espacios del obispado, fascinados por la bonaza económica. Los pobladores de Tuzantla se enfocaron a la cría del ganado mayor y por las minas que pronto se comenzaron a explotar la producción de plata ${ }^{31}$.

La existencia de grandes extensiones de tierra ocupadas por cañaverales y que una de sus haciendas, San Antonio, contara con un trapiche, propició el escenario perfecto para ejemplificar el desarrollo del sincretismo entre pobladores con distintos arquetipos culturales en el siglo XVIII. Es decir, la presencia significativa de diversos grupos que participaban en el proceso productivo e industrial del procesamiento de la caña a la fabricación de azucares y por ello, convivían en los distintos niveles en que propiciaban los intercambios que implicaban momentos como el corte de la caña, su procesamiento en dulce, con la algarabía que alrededor de la fabricación se generaba los días en que los trabajadores recibían su pago, con la llegada de comerciantes que organizaban la distribución del azúcar en los distintos mercados, nos referimos a actores sociales como el administrador que por lo general era un peninsular o criollo, los capataces, trabajadores negros, libres y esclavos. Los primeros formaban parte de las castas, así como los grupos de indígenas provenientes de diversas etnias que allí laboraban.

El arribo constante de trabajadores eventuales acrecentaba el espíritu bullicioso que envolvía al lugar de Tuzantla. Esos hombres que al concluir sus labores y antes de regresar a sus lugares de origen o tareas agrícolas en sus propias tierras, cuando las poseían, celebraban las bondades de una buena cosecha con actos religiosos y la 
consabida presencia de fiestas mundanas, desbordadas por los sonidos de los distintos instrumentos regionales y la algarabía de quienes en pequeños espectáculos hacían suertes de reata, montaban novillos y toros para mostrar sus habilidades de jinetes experimentados. Mientras otros, apostaban a los gallos o lanzaban las cartas en busca de mejorar su suerte. Eran días de intenso movimiento, en que se mudaban al lugar pequeñas compañías itinerantes de circos, prestidigitadores, magos y encantadores; se organizaban las peleas de gallo y se practicaban toda clase de juegos de azar. Atraídas por la bonanza se hacían ver las prostitutas, los yerberos, curanderos, entre otros ${ }^{32}$.

\subsection{Juan Rosales un hechicero de Tuzantla en 1732}

Corría el año de 1732, un día 22 de febrero durante la zafra cuando la mulata Lorenza Pérez, doncella y vecina de Tuzantla, se presentó ante el provisor Juan Joseph de Alcores cura beneficiario del mismo partido para levantar una denuncia en contra de un indio llamado Juan Joseph de la Cruz Rosales originario del Joconusco y de quien señaló aparentaba la edad de 50 años y era viudo de Manuela de la Cruz. Este indio con título de doctor hizo curar de hechizos a la mulata Lorenza Paredes y en su encuentro con el juez Alcores y bajo juramento hecho por Dios nuestro Señor, y la señal de la Santa Cruz, denunciaba:

"Es cierto que estando accidentada de un dolor de estómago muy vehemente descreyendo que era maleficio que me hubieren hecho. $\mathrm{Y}$ teniendo noticia mi madre que un indio llamado Juan Rosales curaba dicho maleficio, lo llamó a que curara, y con efecto el día jueves nos encontramos con él 22 del corriente mes de febrero lo puso en ejecución. Para ello me hizo desnudar. Y estando en un tapete, y habiendo traído unas brasas echó en ellas porción de copal, y me echó en el cuerpo un paño y con él me anduvo tocando brazos y lo demás del cuerpo. Y luego me vi denigrada todo el cuerpo frotándome infinidad de espinitas pequeñas que saltaban y se meneaban, y asimismo muchísimas palomitas negras y todo lo expresado lo fue revisando con dicho paño el dicho Juan Joseph y lo echó en las brasas donde estaba el copal, y expidió un hedor muy grande. Y luego me sentí de todo buena. Y cuando me estaban curando me hizo dicho Juan Joseph, que estuviese rezando el credo en voces altas. Y lo propio que hicieron los que estaban presentes a dicha cura, lo fueron un mulato llamado Alejo y su mujer Ignacia; y dicha mujer llamada Serafina mujer de Esteban mulato, y al tiempo de curada mandó dicho Juan Joseph, encendieran muchas velas así lo hicieron, después de haber curado me dijo dicho Juan Joseph que ya estaba buena que lo que tenía era aire que me habían echado para dañarme, al otro día volvió dicho curandero a curarme y me desnudó medio cuerpo y arriba, me tendió en el petate y me echó copal y unas brasas y cogiendo con sus manos su humo me lo fue poniendo en el medio cuerpo y piernas y mientras me estuvo curando me mandó tuviese en la mano un santo crucifijo y que rezara el credo y así lo hice" ${ }^{33}$.

El mismo día se presentó Alejo Catón, mulato, casado con Ignacia Vergara, vecinos del partido de Tuzantla, de una edad aproximada de 35 años, él había presenciado el ritual curativo, y como testigo en su declaración dijo lo siguiente:

"Me hallé presente en la cura que hizo Juan Joseph Rosales a Lorenza Paredes y vi como la puso en cueros sobre un tapete (...) y le echó un paño en el medio cuerpo con él se lo anduvo pasando y luego vi que le empezaron a brotar en dicho cuero a la dicha Lorenza infinidad de espinitas y palomitas negras que se le puso todo el cuerpo negro, y con dicho paño le fue recorriendo todo lo expresado el dicho Juan Joseph y llevó al estómago sobándolo envuelto lo echó sobre dichas brasas y se soltó un hedor muy grande, le hizo decir a la paciente que no sentía dolor ninguno, y que al tiempo que la estuvo curando el dicho curandero le hizo así a la declarante como 
a la paciente y demás que estaban presentes que el que rezasen en altas voces el credo y que se encendieran muchas velas" ${ }^{34}$.

31 Posterior a la declaración de Alejo como primer testigo, siguió su esposa Ignacia Vergara, mulata libre, quien bajo juramento expresó decir la verdad en lo que supiere en relación a la curación hecha por Rosales a Lorenza, y el mismo 22 de febrero, manifestaba:

"Me hallé presente en una cura que Juan Joseph Rosales indio le hizo a Lorenza Paredes a quien vi que mandó desnudar a dicha Lorenza y la tendió en un petate y habiendo puesto una porción de lumbre echó en ella dicho Juan Joseph copal y luego le echó en el medio cuerpo y arriba un paño y con él le empezó a traer el cuerpo y a este tiempo le fueron brotando a dicha Lorenza de dicho cuerpo muchísimas espinas negras pequeñas y muchísimas palomitas asimismo negras que se le puso todo el cuerpo negriado (sic) y luego el dicho Juan Joseph con dicho paño le fue recorriendo dicho cuerpo llevándoselo para el estómago y allí lo amontonó y envolvió el dicho paño y lo echó en dicha lumbre y se soltó un hedor muy grande y entonces le dijo dicho curandero a dicha Lorenza que ya estaba buena y que con efecto se levantó buena y sana de un dolor vehemente que padecía en el estómago (...) cuando el dicho curandero estaba haciendo dicha cura mandó así a la paciente como a todos los que estábamos presentes que rezasen en voces altas el credo y que así lo hicieron todos" 35 .

Serafina Bautista, casada con Esteban Gallegos -ambos mulatos y vecinos del partido-, de edad de 30 años se presentó también a aportar su versión del ritual de curación hecho a Lorenza Paredes y al que también había asistido:

"Habiendo tenido noticia que Lorenza Paredes mulata de dicho trapiche padecía un riguroso mal de estómago y que se le atribuía a que fuese maleficio, luego que la quería curar un indio curandero llamado Juan Joseph Rosales, lo que en efecto el día que se expresa en dicho acto me hallé presente a dicha cura y vi como el dicho Juan Joseph mandó desnudar a dicha Lorenza y estándolo la tendió en un tapete y junto a ella mandó poner muchas brasas y en ellas echó un copal y la tendió a dicha Lorenza un paño que le cedió de medio cuerpo para arriba y que con le anduvo trayendo el cuerpo y que luego vi como de él brotaron muchísimas espinas prietas y muchísimas palomitas pequeñas asimismo prietas que se le puso todo el cuerpo muy negro, y que dicho curandero con dicho paño le anduvo recorriendo lo expresado y se lo juntó en el estómago y allí la envolvió en dicho paño y lo echó en dicha lumbre y empezó a heder muchísimo y le oí decir al curandero que ya estaba mejor la dicha Lorenza a quien vi levantaba buena y sana, y que al tiempo que le estaba trayendo dicha cura mandó dicho Juan Joseph Rosales que encendieran muchas velas y que así la paciente como todos los presentes, rezaren con voces altas el credo y que así lo hizo todo, después fui a mi casa y le conté todo lo expresado a mi marido" 36 .

Esteban Gallegos, mulato, vecino del partido en su testificación ante el juez el mismo 22 de febrero, al igual que su esposa, señaló:

"Vi como dicho Juan Joseph hizo desnudar demedio cuerpo y de arriba a la dicha Lorenza y la tendió en un petate y le puso un santo crucifijo en las manos y en unas brasas echó copal y cogiendo el humo de él con las manos se lo aplicó en dicho medio cuerpo y en las piernas, y que dijo dicho Juan Joseph que ya estaba buena, y que cuando le estaba curando le mandó a la paciente y a mí que rezáramos en altas voces y que encendiéramos velas y que así le hizo todos" ${ }^{37}$.

Esteban en esa misma declaración confesó que mucho antes de que Lorenza Paredes recibiera cura, él ya había asistido con el mismo curandero, y en su calidad de testigo, dijo: 


\begin{abstract}
"Estando padeciendo de una crecida llaga en la pierna y que aunque me había puesto en cura me echó varios medicamentos, no me aliviaba en nada ante sí, sentía mayores dolores que lo atribuí a maleficio, tuve noticia de lo acertado que era dicho Juan Rosales lo llamé para que me curase y con efecto vino y toda la cura se redujo a echar un poco de copal en la lumbre y sumar con él, y mientras me estuvo curando mandó que rezasen el credo y otras oraciones en voces altas y encender luces y que luego quedé bueno y sano"38.
\end{abstract}

Bajo esta primera descripción, que en sus respectivas declaraciones hicieron la denunciante y los testigos, inicia el motivo de la causa criminal contra la fe que se siguió por el Tribunal Eclesiástico en contra de Juan Rosales un indio hechicero originario del Joconusco. Lorenza Paredes la enferma y denunciante en la documentación previa su declaración quedó registrada como una mulata, doncella y vecina del partido con residencia era el trapiche de San Antonio. De acuerdo con el Curso de derecho canónico hispano e indiano, que sirvió de manual para procesar este tipo de casos cuando éstos se presentaban el denunciante tenía la obligación de probar la existencia de un delito del que anuncia señalando a un sospechoso. Una vez recibida la denuncia y llamado a los testigos, el juez inicia las averiguaciones correspondientes en que debía verificar la calidad moral de la denunciante y los testigos ${ }^{39}$.

36 Al levantar el testimonio de delito proporcionado por un denunciante, el juez debía instar a un interrogatorio, para escuchar de viva voz de los involucrados los detalles de los hechos que probaran en primera instancia la existencia de un delito en contra de la fe. Para el caso que nos ocupa, Lorenza Paredes proporcionó la denuncia-testimonio bajo juramento hecho ante Dios Nuestro Señor y la Señal de la Santa Cruz. En este sentido hay que tener en cuenta que cuando se estaba frente a un juez y se juraba en nombre de Dios tanto denunciantes como testigos quedaban obligados a decir la verdad, pues el hecho de dar falso testimonio era un pecado que a la vez, por haber sido bajo juramento debía ser sancionado, y éste no podía ser perdonado bajo el sacramento de la confesión ante un tribunal que velaba por los cánones de la doctrina ${ }^{40}$.

La protección que desde el Tercer Concilio se tenía de los indios para recibir un justo proceso en la impartición de justicia, propició que los denunciantes y los testigos, usaran la figura de descargo de conciencia para justificar sus acusaciones, y haber formado parte de los hechos que denunciaban. La descarga de conciencia era una apología de confesión. Una persona cristiana hacia uso de la obligación que tenía para señalar a quién se consideraba cometía un crimen contra la fe. Bajo ese recurso, aunque hubiera participado en los hechos, recibía el perdón por proporcionar al juez información incriminatoria. De esa manera quien denunciaba sobre hechos conocidos salvaguardaba su alma. El testimonio que proporciona al juez eclesiástico bajo juramento se detallaba al inicio del expediente que se levantaba para seguir el debido proceso.

Las declaraciones de los testigos ofrecen información valiosa de los procedimientos seguidos en un juicio eclesiástico y los distintos momentos por los que debía transitar el mismo. Una vez levantada la demanda, se estipulaba que el libelo debía ser breve y no debía contener los detalles innecesarios. El juez con ayuda del notario eclesiástico, tomaba nota de los acontecimientos que creía convenientes para que pudiera iniciarse la fase sumaria ${ }^{41}$. Para que una investigación fuese oficial, la denuncia debía dejar anotados los datos de los involucrados y los nombres de las personas que pudieran ser testigos $^{42}$, por lo cual en el protocolo seguido, debía incluirse el nombre del juez, el 
nombre del demandante, a quién se demanda y explicarse las causas del por qué se demanda. De acuerdo con el texto de Pedro Murillo que sirvió como manual:

"El libelo debe contener clara petición del actor y por lo tanto, en él debe ponerse: 1. El nombre del juez al que se presenta, que si no el nombre propio de aquél, al menos el de su oficio, para que se sepa si es competente o no. 2. El nombre del actor y si éste actúa en nombre de otros, también ponerse el nombre del actor principal.

3. El nombre del demandado contra el que se actúa" ${ }^{\text {"3 }}$. Paredes el 22 de febrero de 1732. En la medida en que se acumularon los testimonios se sentaban las evidencias de que el indio a quien se acusaba de practicar la hechicería no era la primera vez que se le encontraba curando en esa región del obispado. Esteban Gallegos, uno de los testigos en su declaratoria hizo saber al juez que mucho antes de que Lorenza Paredes recibiera la cura él había acudido a Juan Rosales para que lo tratara también. Ahora bien, habíamos mencionado que las prácticas curativas vinculadas a la hechicería eran una actividad que se realizaba con mucha frecuencia entre la población, a pesar que se conocía que con ello se violentaba las leyes eclesiásticas, sin embargo, la mayoría de las veces los curanderos contaban con la aceptación y el disimulo por parte de los vecinos y fueron pocas los casos que llegaron a los tribunales, como expresamos al revisar los expedientes en el archivo.

y no encontraron la cura. En la mayor parte de los casos consultados éstos se produjeron después de haber acudido al servicio de un curandero o porque se tenían divergencias con algún vecino y en la enfermedad que los aquejaba venía el origen de su maldad. Así que cuando el mulato Esteban en su testimonio hizo referencia a las capacidades curativas que ejercía Rosales posiblemente él fue quien recomendó a la madre de Lorenza Paredes para que hiciera uso de los servicios del indio de Joconusco aunque no descartamos la popularidad de nuestro curandero puesto que para la época y 
la falta de médicos las actividades supersticiosas eran un recurso de los pobladores para sanar sus males. Su silencio para denunciar el hecho cuando acudió a Juan Rosales para que lo curara, es otra prueba del reconocimiento que tenía el curandero por sus buenos oficios entre la población y la complacencia con que los vecinos actuaban para dejarlo desarrollar su labor.

De las declaraciones descritas en el documento por los testigos se puede inferir la mezcla de representaciones utilizadas por Rosales en la curación que aplicó a Lorenza Pérez las cuales derivaban de diversas tradiciones culturales y religiosas de naturaleza distinta, lo que a su vez nos habla de la intensidad con que se conservaron y asumieron para el siglo XVIII en la región de estudio, principios de los rituales religiosos de origen indígena sobrepuestos a otros de carácter africano con elementos del cristianismo occidental. Esta serie de tamices a su vez deja ver el papel de Tuzantla como una región de transito comercial, con una diversidad de expresiones culturares que coinciden con la manera en que se insertaron a la región diversos grupos sociales, conformados por peninsulares, criollos, negros libres y esclavos, mulatos, pardos e indios. Varios de los elementos utilizados por Rosales en su curación como describiremos a continuación, en el siglo XVIII fueron concebidos por el Tribunal como pruebas irrefutables de la actividad delictiva del indio contra la fe.

En los métodos curativos aplicados por Rosales y descritos en la denuncia aunada a los testimonios que en su contra se registraron en el expediente encontramos aspectos de las transformaciones culturales y religiosas registradas en las concepciones curativas indígenas de la época; así como la apropiación de diversos valores religiosos como ya se ha dicho. El hecho de tumbar a la paciente en una manta o petate, la incorporación en el ritual de las brasas de copal y el humo blanco derivado de ellas, la utilización de velas para mantener el simbolismo legendario que ha representado el fuego y el acto intermediador de las oraciones, se encuentra en diversos lienzos y testimonios visuales que han llegado hasta nosotros, como parte de las curaciones entre los náhuatl y mayas ${ }^{45}$.

La utilización del copal entre diversos grupos indígenas mesoamericanos estaba relacionada con las ceremonias religiosas y curativas tradicionales ${ }^{46}$. Su nombre proviene del náhuatl copalquahuitl, que refiere al árbol que crece en las zonas selváticas y semiáridas de México. El copalli era utilizado como ofrenda a las deidades y por sus propiedades terapéuticas también era usado para aliviar algunas dolencias ${ }^{47}$. Juan Rosales en la curación que aplicó a Lorenza Paredes, lo emplea en los dos sentidos, pues cuando el copal se quema en brasas produce un humo blanco con el que se invoca el favor de los Dioses. Al ser inhalado por el paciente estimula su olfato llevando así las propiedades curativas al sistema límbico y anima sus emociones, al disminuir la sensación de pena o angustia. La ignorancia que tenía la población sobre la función química que las plantas curativas hacían efecto sobre las enfermedades permitía darle un valor de credibilidad a los rituales curativos y como resultado los curanderos escalaban en la popularidad como buenos médicos de lo fisiológico y emocional.

En su denuncia Lorenza Paredes describe que con un paño el indio curandero recorrió su cuerpo, mientras realizaba esa acción posiblemente oraba aunque no se registra en los documentos que lo hiciera. La razón de recorrer el cuerpo de la enferma con un paño era para que el copal al ser quemado y soltar una resina en combinación con varias yerbas produjera un humo blanco que para las sociedades prehispánicas era el elemento que representaba la comunión de la tierra y el cielo ${ }^{48}$. Al frotar esta resina - 
como hizo Rosales con el cuerpo de su paciente- se obtiene la disminución o desaparición de dolores de hueso, dentales, jaquecas y padecimientos bronco pulmonares relacionados con las creencias de lo frío y caliente en la enfermedad. Además que proporcionaba la cura de ojos, esputo de sangre, flemas amarillentas, hipo, úlceras, estómago, corazón, epilepsias, entre otros ${ }^{49}$. El copal también ha sido utilizado en el ritual curativo de Rosales como medio de protección utilizado en los conjuros o con fines mágicos ${ }^{50}$.

En la descripción que se hacen de los hechos destaca la presencia de otras personas quienes además de rezar en voz alta, son las encargadas de sostener las velas prendidas como símbolo sagrado del fuego que servía para alejar las fuerzas malignas durante la cura y para que el curandero obtuviera la sabiduría (luz) para sanar el cuerpo enfermo. El fuego también es uno de los elementos litúrgicos de adoración más antiguos utilizados por los católicos, mientras que en las culturas africanas la presencia del fuego en ritos curativos era la forma de rendir culto al sol, a la vida. Orar en voz alta el credo, remitía a refrendar la fe en la existencia de Dios, a quien Lorenza al sostener en sus manos la representación de un crucifijo invocaba en su autoridad para que se le concediera la salud, mientras que el curandero, que hacía las veces de chaman o intermediario, ayudaba a aliviar sus males ${ }^{51}$. El sincretismo que desenvuelve las diversas etapas de la terapéutica curativa-religiosa aplicada por Rosales, es un ejemplo del cruce o superposición de creencias y saberes que a lo largo de varios siglos se fueron amalgamando y trasmitiendo de una generación a otra y que están presentes en ese breve acto descrito en la documentación del juicio seguido al indio del Joconusco.

Las palomitas negras y las espinitas pequeñas que le salieron del cuerpo de Lorenza Paredes, junto con el mal olor eran la muestra de la presencia de un mal de hechizos que alguien le había querido causar. Posiblemente eso que todos declararon haber presenciado, se relaciona con los efectos de alucinación que el copal combinado con algunas hierbas podía causar. Por otro lado las velas en un ritual tienen una importancia significativa pues dependiendo del número y color que se colocaban al inicio del tratamiento o de la ubicación que se les diera, servían como un escudo que protegía al curandero para que otros hechiceros o brujos no lo pudieran ver o intervenir mientras aplicaba sus remedios, las velas servía para curar o causar un mal ${ }^{52}$.

Ahora bien en la primera mitad del siglo XVIII en la Nueva España la utilización de oraciones, ensalmos y conjuros, o el uso de figuras cristianas, como los santos y crucifijos fueron expresiones del sincretismo religioso, pues la hechicería y curanderismo fueron actividades cotidianas desarrolladas y buscadas por los novohispanos ${ }^{53}$. En la información que deriva de la denuncia de Lorenza Paredes, esos actos no hubieran sido registrados por el Tribunal, sin la existencia de una denuncia, que era el instrumento legal para que una institución como esa interviniera.

De acuerdo con el protocolo que para un caso de hechicería se debía seguir, después de que los testigos se habían presentado ante el juez eclesiástico acompañado del notario y una vez analizados los hechos se dictaba sentencia. En el caso de Juan Rosales, el 26 de febrero de 1732, Salvador Tello en su calidad de notario dejó anotada la culpabilidad de indio. El cura Joseph de Alcores juez eclesiástico quien llevó a cabo la fase sumaria en contra del curandero mandó los resultados del juicio al obispo de Michoacán Juan Joseph de Escalona, quien encontró que con base a la información recabada por las autoridades y los testimonios dados por los testigos se hallaba que Juan Rosales era culpable de un crimen contra la fe por realizar prácticas de hechicería y curanderismo. 
Joseph de Alcores, en su calidad de juez eclesiástico, mandó poner preso al indio haciendo uso del brazo secular. Juan Hernández, quien en ese momento se desempeñaba como alcalde mayor de Tuzantla, cumplió la orden, conduciendo a Juan Rosales a la cárcel pública de ése partido, en donde quedó a disposición de la ley.

\subsection{Juan Rosales ante el juez eclesiástico de Tuzantla}

51 La aplicación de justicia en la Nueva España se componía de dos formas la ordinaria y la civil; regular y secular, ambas trabajaban conjuntamente ${ }^{54}$. El caso que estamos analizando, el juez eclesiástico solicitó la ayuda del alcalde mayor para aprehender a Juan Rosales de esta forma el reo no evadía la ley o al menos así se creía. Una vez que el inculpado fue apresado el 26 de febrero de 1732 y conducido a la cárcel pública de Tuzantla, el juez eclesiástico se dio a la tarea de iniciar su interrogatorio el cual se componía de varios momentos y que hemos desarrollado en forma de dialogo. El primero de ellos era el de tomar sus datos generales, para posteriormente, escuchar su versión sobre los hechos acaecidos, cuatro días antes, el 22 de febrero de 1732 y de los cuales se le inculpaba. El interrogatorio inició de la manera siguiente:

“¿Cómo se llama, qué estado, calidad, ejercicio y edad?

-Me llamo Juan Joseph de la Cruz Rosales, soy indio vecino del partido de Joconusco residente en este partido y soy viudo de Manuela de la Cruz.

¿Por qué está preso y quién lo aprehendió?

-Quien me aprehendió fue su merced el señor cura, y la causa de mi prisión es porque he curado algunas personas de hechizos.

¿Cómo con poco temor de Dios y ningún respeto a su justicia anda en menosprecio de la santa fe, valiéndose de artes diabólicas para curar?

-Es cierto que he hecho varias curas de hechizos, por haber sido gracia de Dios que me ha dado.

¿De qué cosa se vale para hacer dichas curas?

-Con ocasión de haberme accidentado de un brazo donde padecía vehementemente dolores, así me lo llegué a torcer, y habiéndome hecho infinitos remedios, no me asentó ninguno, y habiendo bebido una yerba que llaman Santa Rosa lo hice y después me eché humo de copal y luego sané, con este ejemplar he curado distintas personas, entre ellas a Sipriano Cabrón en dicho pueblo de Joconusco quien estando padeciendo de un vehemente dolor de estómago casi estaba ya muerto, le di a beber dicha yerba Santa Rosa untándole el humo del copal al instante eché por la zona de atrás un muñeco al parecer hecho de queso asadero, después de echarlo quedó bueno y sano hasta el día de hoy. Asimismo al haberme llamado en el trapiche de San Antonio para que curara a una mulata llamada Lorenza Paredes le di a beber la Santa Rosa, la desnudé y puse sobre un petate, quemando el copal, dándole con el humo que cogía en las manos, en el cuerpo y poniéndole un trapo en suma, le encontré en dicho cuerpo muchas espinas y palomitas prietas, recorriendo todo con dicho trapo lo quemé y quedó buena y sana asimismo me valí de que cuando estaba haciendo la cura rezaron en voces altas al credo y encendieron muchas luces. Hasta el presente a todos cuantos he curado de hechizos han sanado.

-¿Qué pacto implícito, o explicito ha tenido el confesante para hacer dichas curas con el demonio? Sabiendo que los hechizos no se producen si no es de un maldito pacto, confiese y diga la verdad, muere que si no lo dice se lo ha de llevar el demonio a sus cóncavos infernales por toda la eternidad.

-No he tenido pacto implícito o explicito con el demonio para hacer dichas curas, sino que ha sido gracia que Dios me ha dado, valiéndome de dar a beber dicha yerba Santa Rosa y untándole el gimo del copal a los dañados y que esto lo he hecho por el interés de que me paguen algunas cosas por mis curas, por ser un pobre" ${ }^{35}$. 
52 expediente nos muestra, deja ver cómo se había dado la yuxtaposición de cosmovisiones. La primera en el momento en que el indio curandero afirmaba que el "don de curar" lo había obtenido por gracia de Dios, nos permite acercarnos a la lógica con que actuaba, la cual estaba estructurada a partir de varios tejidos ideológico culturales desarrollados en la Nueva España. Por otro lado, aunque en el documento, el indio Rosales no especifica la edad en que empezó a ejercer su quehacer de curandero, según algunos autores, el reconocimiento de la flora y sus usos medicinales con fines terapéuticos era una práctica que comenzaba a enseñarse a aquellos indígenas que desde niños se les reconocía una capacidad por relacionarse con el medio natural y que en el siglo dieciochesco, por la serie de epidemias que se sufrieron en la Nueva España (viruela, fiebre amarilla, matlazahuatl, tifo, entre otras), hubo una necesidad -"resurgimiento"- de recurrir a ese tipo de prácticas ${ }^{56}$.

Mientras que desde el tribunal a través del juez y las preguntas que éste hacía al inculpado, se trata de inducir al mismo para que en sus declaraciones ofreciera pruebas en su contra en un proceso donde se juzgaban sus actos contra la fe; en el interrogatorio sobresalen algunos aspectos que eran esenciales para encontrar la culpabilidad del reo: a) la versión del curandero sobre su capacidad de sanar y b) la información de la manera en que adquirió esa capacidad y c) probar que lo hizo con auxilio del demonio. En el interrogatorio y respuestas de Juan Rosales encontramos dos posicionamientos que como se señaló en el párrafo anterior, tienen su origen en cosmovisiones religiosas enfrentadas, pero que para los indígenas del siglo XVIII como la del indio acusado de hechicero estaban empalmadas.

54 A la pregunta: “¿Cómo con poco temor de Dios y ningún respecto a su justicia anda en menosprecio de la santa fe, valiéndose de artes diabólicas para curar?". Es importante señalar que el juez eclesiástico siguiendo el protocolo establecido de la función que debía realizar, parte de la clasificación que se había hecho para identificar actos relacionados con la hechicería a través de expresiones como: "poco temor de Dios", "ningún respeto a su justicia", "la incomprensión de la santa fe" y "valerse de artes diabólicas para curar", como se establecía en los manuales y la legislación. La respuesta que obtiene del acusado es sencilla y se remite a la lógica que podía utilizar un indio que había recibido la doctrina, pero que al mismo tiempo conservaba una parte importante de las raíces y conocimientos de sus ancestros. Juan Rosales, un hombre que para la época era una persona mayor -50 años-, casi un anciano, que en las artes curativas había encontrado una forma de resolver su sustento, reconoce: "Es cierto que he hecho varias curas de hechizos" y agrega, que tuvo ese saber "por haber sido gracias de Dios". Es decir, tiene un don que Dios le concedió. de dos cosmovisiones religiosas amalgamadas, sino también de dos lenguajes o formas de nombrar las cosas en franco desencuentro. Al adentrarnos al análisis del caso, estas diferencias se van subrayando y nos descubren la presencia de un conocimiento ancestral acumulado que en algún momento le fue trasmitido a Rosales y que ahora ejecutaba sin preocuparse o poner en duda sus fundamentos. Como él mismo lo hace saber cando el juez le interroga:

56 “De qué cosas se vale para hacer dichas curas?” El juez aunque continua en su labor inquisitiva siguiendo lo que indica la Ley, en el hecho de que Rosales declare el uso de objetos religioso católicos (crucifico, ensalmos, etc.), figuras maléficas (muñeco de 
queso asadero) en sus estrategias curativas, encuentra pruebas suficientes de incriminación e intervención diabólica. Nuevamente la respuesta de Rosales da luz de la forma en que el indio de Joconusco, en sus prácticas curativas, incorpora diversas tradiciones, que para el momento eran perseguidas. Los saberes que sobre la naturaleza y las propiedades curativas o venenosas tienen algunas plantas, los cuales le habían sido trasmitidas y que con el paso del tiempo fue acumulando; y el poder de plegarias como el credo, que si se rezaban en voz alta y por un grupo de personas, adquirían mayor resonancia para que fueran escuchadas y atendidas por Dios. Aunada a la afirmación cristiana en representaciones como el crucifico y la utilización del fuego.

En cuanto a la pregunta y amenazas lanzadas por el juez respecto de:

"¿Qué pacto implícito o explicito ha tenido el confesante para hacer dichas curas con el demonio? Sabiendo que los hechizos no se producen si no es de un maldito pacto, confiese y diga la verdad, muere que si no lo dice se lo ha de llevar el demonio a sus cóncavos infernales por toda la eternidad".

58 El indio sin perder la cordura, con tranquilidad contestaba al magistrado: "No he tenido pacto implícito o explicito con el demonio para hacer dichas curas" y sin salirse de su posición, volvía a reiterar: "ha sido gracia que Dios me ha dado". En tanto que la yerba Santa Rosa y el copal que eran los recursos curativos de que se valió para realizar su labor, eran para él, el medio para lograr la sanación de las personas. Finalmente, Rosales hace saber el juez que ejerce ese quehacer "por el interés de que me paguen algunas cosas por mis curas, por ser un pobre".

La hechicería y el curanderismo fueron actividades las cuales con el intercambio cultural entre pobladores de la Nueva España, la protección del indio a través del Tercer Concilio y derecho indiano subsistieron a lo largo de la época colonial. Las prácticas curativas por lo tanto representaron en muchas ocasiones, una solución viable para sanar las enfermedades fisiológicas y emocionales. A pesar de que en la colonia existió una institución como el Protomedicato que legitimaba el oficio de cirujanos, médicos, boticarios, parteras etc., se sabe que hubo una cierta tolerancia en las prácticas médicas que realizaban en la Nueva España personas sin profesión, debido al escaso número de médicos que había ${ }^{57}$. Los indígenas por su parte de manera frecuente en sus prácticas curativas acudían a la herbolaria.

60 En su declaración Juan Rosales hace saber al juez que en alguna ocasión utilizó un muñeco de queso asadero en su labor. El uso de figurillas enfatizaba una de las maneras de representar el daño corporal que se le causaba a una persona. Los muñecos eran utilizados para causar maleficios o para curar de hechizos, como se entiende hizo el indio de Joconusco. Autores como Marta López sostienen que la concepción de los muñecos para realizar un hechizo se basó en crear una figura similar a la imagen de la persona a la que se quería curar o dañar. De esta manera era posible manipular su voluntad, en la cual se podía causar daño al encajar o perforar al muñeco por medio de agujas y alfileres o se podía revertir el mal a quien lo estaba causando. La creación de los muñecos estuvo extendida por toda la Nueva España y fueron utilizados por los diversos grupos de la sociedad. Los indios los fabricaban de masa de maíz, los españoles los hacían de cera y los negros de trapo.

61 La Santa Rosa que Juan Rosales utilizó era una hierba empleada con frecuencia en los rituales curativos. Recibe su nombre de Santa por su olor. Esta yerba ejerce un poder que por medio del trance "habla" o conduce al "conocimiento" para saber quién o quiénes han causado el mal, además tiene el significado mágico de que propicia la 
comunicación de un mundo a otro y con los entes que ahí radican ${ }^{58}$. Así que cuando Juan Rosales indicaba su iniciación como curandero "por gracia de Dios", al utilizar esta planta en sus recursos curativos, y hacerla ingerir a sus pacientes, provocaba en ellos un estado de trance, lo que nos lleva a suponer que cuando usó la Santa Rosa para curarse a sí mismo, al estar en trance, en sus alucinaciones pudo creer que habló con Dios o tuvo algún encuentro con esa deidad. La otra forma de interpretar la respuesta lacónica de Rosales, es que su habilidad de conocer las propiedades curativas de ciertas plantas nace y la aprende desde niño, por ello, lo considera "una gracia que Dios le dio" 59 .

62 Una vez reunidas las pruebas en contra del indio Juan Rosales, siguiendo con el proceso, éste fue juzgado y declarado culpable por haber cometido un crimen en contra de la fe. El 26 de mayo de 1732, año en que se abrió el expediente, el provisor fiscal ordenó fuera encarcelado y se pusiera guardia para custodiar la celda donde se encontraba preso. Asimismo se ordenó que se iniciara una averiguación para conocer si Rosales poseía bienes, pues como estaba previsto en la legislación de la época, si el indio tenía propiedades éstas le serían confiscadas ${ }^{60}$. El día 15 de junio del año 1732 el alcalde mayor Juan Hernández informó al licenciado Rada, vicario general del obispado de Michoacán, que Juan Rosales había escalado la pared de su celda y escapado de la cárcel, y que hasta el momento no se habían tenido noticias de su ausencia ${ }^{61}$. Posteriormente al mismo Juan Rosales se le llevó acabo otro juicio por hechicero en la región de Zitácuaro en el año de 1732.

De lo expuesto hasta ahora se puede señalar, que en el desarrollo seguido al proceso que se abrió en contra de Juan Rosales por practicar la hechicería y curanderismo, encontramos que la actuación de Juan Joseph de Alcores, cura beneficiario del pueblo de Tuzantla como juez eclesiástico, en su actuar se apegó a los procedimientos establecidos a los Tribunales Ordinarios, para resguardar el justo proceso que debía recibir los naturales, en este caso Rosales, derivado del derecho indiano y los estatutos del Tercer Concilio Mexicano que analizamos en el capítulo anterior, hasta antes de recibir sentencia.

El expediente derivado del caso del indio Juan Rosales, después de que éste se escapó de la cárcel se interrumpe y no aporta mayor información. Sin embargo podemos afirmar sustentándonos en el manual de derecho canónico de Murillo Velarde, que el juicio quedó anulado, pues en ese documento se decía que un juez no tenía jurisdicción sobre la causa en otro partido. Por otro lado, se advertía que la sentencia también quedaba sin ejecución, pues el juez que la había dictado era el que debía ejecutarla. Las limitaciones legales expuestas para el caso que nos ocupa, posibilitaron que el indio curandero originario del Joconusco, al escapar de la cárcel y huir de la jurisdicción de Tuzantla en donde operaba ese tribunal, antes de recibir castigo, recuperara su libertad y el delito por el que se le había acusado, quedara impune ${ }^{62}$.

65 Finalmente a lo largo del trabajo pudimos analizar el papel que desempeñaron los Tribunales Ordinarios en la región oriente del obispado de Michoacán y la manera en que eran atendidos los casos en que los indios eran acusados de crímenes contra la fe. El hecho de que los indios estuvieron a cargo de obispos y provisores generales, en concordancia con su personalidad jurídica, posibilitó que al momento de ser denunciados, correspondiera a la autoridad de los jueces eclesiásticos, garantizar que éstos recibieran un justo proceso. El caso de Rosales ilustra los procedimientos que estaban obligados a realizar los jueces eclesiásticos desde la fase sumaria, hasta la 
declaración de la sentencia y castigo. El derecho canónico fue utilizado como marco referencial para llevar acabo la impartición de justicia en los crímenes contra la fe. En el juicio encontramos que el actuar del juez siempre se apegó a lo establecido en el derecho.

\section{Conclusiones}

La condición jurídica de los indios durante la época colonial permitió la instauración de una institución que aplicó la justicia cuando los naturales transgredían la religión católica, su moral y ponían en entredicho la fe, en ese sentido, desde el Tercer Concilio Provincial Mexicano se sentaron las bases para establecer un sistema gubernativo el cual permitiera proteger a los naturales de las injurias a las cuales estaban sujetos. Asimismo a través del castigo se establecía una protección del indio puesto que no se le juzgó como viejo cristiano lo que significó que no pasaba por el tormento ni recibía penas capitales. En ese tenor, la instauración del Tribunal Ordinario propició una justicia casuística pues dependía de la interpretación del juez identificar cuándo se había cometido un crimen de hechicería, una práctica común en la Nueva España que a falta medicamentos, cirujanos y médicos los pobladores novohispanos recurrían a los curanderos y hechiceros como se vio expuesto en el caso que analizamos.

Este nos permitió conocer cómo era la postura de un juez al interrogar al actor, testigos y reos en un juicio, su obligación era buscar aquél pacto implícito y explicito con el diablo, en este sentido se vislumbró la postura institucional del tribunal con la utilización de cuestionamientos que permitieron conocer a detalle cómo se ejercía la curación en la región oriente de Michoacán, la casuística aplicada parte del crimen que el indio cometió y cuáles eran los elementos que fungieron como evidencia para reconocer una trasgresión.

La riqueza del documento que forma parte del expediente nos permitió detectar la profundidad y raíces diversas que permeaban las costumbres religiosas y culturales de la sociedad novohispana. De tal forma que aun cuando los documentos consultados forman parte de un juicio que inició con una denuncia en contra de un indio curandero a quien se acusaba de practicar la hechicería, en las declaraciones y datos que proporcionan los denunciantes y testigos, está presente el reconocimiento que sobre las funciones curativas que efectuaba Rosales. Mientras que en las estrategias utilizadas por el indio de Joconusco para sanar a sus pacientes detectamos la presencia de diversas tradiciones socio-culturales, las cuales revelan la mixtura de diversas herencias rituales, que van de los usos y conocimiento de las propiedades botánicas y curativas de determinadas plantas medicinales; al empleo de símbolos y representaciones religioso-católicas, prehispánicas y africanas. El hecho de que en el juicio encontremos la intervención y actuación de indios y mulatos nos permite detectar que en una sociedad estamental y dividida en castas como era la novohispana, la superstición cohabitaba en cada uno de los grupos ante la falta de posibilidades para explicarse el tipo de conocimientos de que hacía uso Juan Rosales para curar.

\section{Fuentes}

Archivo Histórico de la Casa Natal de Morelos (en adelante AHCNM), Fondo diocesano (Fondo Diocesano), Justicia (J), Procesos Criminales (PC), Hechicería (H), Caja 834 (C), 
Expediente 1 (E), Causa criminal que se siguió en contra de Juan Rosales, acusado ante el juez del partido de Tuzantla por practicar la hechicería, 22 de febrero de 1732.

\section{BIBLIOGRAFÍA}

Aguilar Rivera, Noé, “La caña de azúcar y sus derivados en la Huasteca San Luis Potosí México", Diálogos Revista Electrónica de Historia, Costa Rica, vol. 17, n¹, 2010, p. 81-110.

Aguirre Beltrán, Gonzalo, Medicina y magia. El proceso de aculturación en la estructura colonial, México, Instituto Nacional indigenista, 1987.

Alberro, Solange, Inquisición y sociedad en México 1571-1700, México, Fondo de Cultura Económica, 1988.

Báez Cubero, Lourdes, "El uso del ritual de la 'Santa Rosa' entre los otomíes orientales de Hidalgo: el caso de Santa Ana Hueytlalpan”, Cuicuilco, México, Escuela Nacional de Antropología e Historia, vol. 19, n53, 2012, p. 154-174.

Balderas Sánchez, Norma, "La herbolaria en la Nueva España y su empleo en la botica del Colegio de Vizcaínas 1775-1780", Multidisciplina, México, Facultad de Estudios Superiores, Universidad Nacional Autónoma de México, ${ }^{\circ} 11,2012$, p. 47-59.

Cagni, Horacio, "Reflexiones en torno a los conceptos de guerra justa y cruzada en su actual revalorización”, Revista enfoques, Chile, vol. VII, n¹0, 2009, p. 157-181.

Campos Moreno, Araceli, “Textos mágicos del Archivo Inquisitorial de la Nueva España”, Literatura Mexicana, México, Universidad Nacional Autónoma de México, vol. 5, n¹, 1994, p. 173-200.

Cardozo Cardona, John Jairo, "El desconocimiento del indio y la colonización: entre el mito y la fantasía”, Revista Virtual, Colombia, n¹5, 2005, p. 1-15.

Cebreiros Álvarez, Eduardo, “La condición jurídica de los indios y el derecho común: un ejemplo del 'favor protectionis' ”, Panta Rei, Italia, vol. 1, 2004, p. 469-489.

Chávez Guzmán, Mónica, “Médicos y medicinas en el mundo peninsular maya colonial y decimonónico", Península, Mérida, Universidad Nacional Autónoma de México / Centro Peninsular en Humanidades y Ciencias Sociales, vol. VI, n², 2011, p. 71-102.

Chazaro Basañez, Miguel \& Mostul, Brun L. \& García Lara, Feliciano, "Los copales mexicanos", Bouteloua. Revista científica internacional dedicada al estudio de la flora ornamental, España, Floramontiberica, vol. 7, 2011, p. 57-79.

Ciruelo, Pedro, Reprobación de las supersticiones y hechicerías, España, Maxtor, 2005.

Coli Hurtado, Atlántida \& María Teresa Sánchez Salazar, "La minería en el obispado de Michoacán a mediados del siglo XVIII" en Investigaciones Geográficas, México, Universidad Nacional Autónoma de México, Boletín 39, 1999, p. 109-121. 
Cortés Máximo, Juan Carlos, De repúblicas de indios a ayuntamientos constitucionales: pueblos sujetos y cabeceras de Michoacán, 1710-1831, México, Instituto de Investigaciones Históricas-Universidad Michoacana de San Nicolás de Hidalgo, 2012.

Cunill, Caroline, "El indio miserable: nacimiento de la teoría legal en la América colonial del siglo XVI", Cuadernos Inter.C.A.mbio sobre Centroamérica y el Caribe, Costa Rica, año 8, n9, 2012, p. 229-246.

Espejel Carbajal, Claudia, "Caminos centenarios del altiplano michoacano de la tierra caliente", en Long Towell, Janet \& Attolini, Lecón Amalia (coords.), Caminos y mercados de México, México, Universidad Nacional Autónoma de México, Instituto Nacional de Antropología e Historia, 2009, p. 389-410.

Eymeric, Nicolau, Manual del inquisidor, México, Alama Clásicos, 2003.

Foucault, Michel, Vigilar y castigar, México, Siglo XXI Editores, 2014.

Galván Rivera, Mariano, III Concilio Provincial Mexicano, Celebrado en México el año de 1585, confirmado en Roma por el Pala Sixto V, y mandado observar por el gobierno español en diversas reales Ordenes, México, Eugenio Mallefert y Compañía Editores, 1959.

García de Verón, María Esther, "El cabildo de Córdoba ante el Tribunal del Protomedicato de Buenos Aires", ponencia presentada en XI Congreso del Instituto de Historia del Derecho Indiano, Buenos Aires, 4-9 de septiembre, 1995.

García Martínez, Luz Elena, “Aspectos socio-ecológicos para el manejo sustentable del copal en el ejido de Acateyahulco, Gro.”, Tesis de Licenciatura en Ciencias Ambientales, Centro de Investigaciones en Ecosistemas, Universidad Nacional Autónoma de México, México, 2012.

Gargallo García, Oliva, La comisaría inquisitorial de Valladolid de Michoacán, México, Universidad Michoacana de San Nicolás de Hidalgo, Instituto de Investigaciones Históricas, 1999.

Gómez, Alfredo, "Sobre la legitimidad de América: Las Casas y Sepúlveda", Ideas y valores Revista Colombiana de Filosofía, Colombia, vol. 40, n85-86, 1991, p. 3-18.

González Lozano, María del Carmen \& María Guadalupe Almeida López, “El Protomedicato” en Soberanes Fernández, José Luis, Memoria del III Congreso de Historia del Derecho Mexicano (1983), México, Universidad Nacional Autónoma de México, 1984, p. 309-317.

Greenleaf, Richard E., La inquisición en Nueva España siglo XVI, Fondo de Cultura Económica, 1981.

Gruzinski, Serge \& Carmen Bernand, De la idolatría una arqueología de las ciencias religiosas, México, Fondo de Cultura Económica, 1992.

Guzmán Pérez, Moisés, "La conquista y la dominación española" en Tuzantla historia en la tierra caliente, México, Ayuntamiento Constitucional de Tuzantla, 1991.

Hernández Hernández, Adalberta Alejandrina \& López Santiago, María del Carmen \& Méndez Hernández, Ángeles \& Jael Morales López, Herbolaria oaxaqueña para la salud, México, Instituto Nacional de las Mujeres, 2009.

Limón Olvera, Silvia, El fuego sagrado, simbolismo y ritualidad, entre los nahuas, México, Universidad Nacional Autónoma de México, 2012.

Linares E. \& Bye R., "El copal en México", Biodiversitas, México, Comisión Nacional para el Conocimiento y uso de la Biodiversidad, $n^{\circ} 78,2008$, p. 8-11.

López Melero, Monserrat, Evolución y sistemas penitenciarios y de la ejecución penal, España, Anuario de la Facultad, Universidad de Alcalá, n5, 2012. 
López Pereda, Marta, “Superstición, brujería y esclavitud en una sociedad colonial: Nueva España a mediados del siglo XVIII”, Tesis de Maestría en Historia, Facultad de Filosofía y Letras, Universidad de Cantabria, Cantabria, España, 2014.

Martínez Ferrer, Luis, "Las Órdenes mendicantes y el sacramento de la confesión en Nueva España (siglo XVI)", Revista Complutense de Historia de América, Madrid, n 48, 1998, p. 47-68.

Martínez Garrido, Carmelo, “Juan José de Escalona y Calatayud, su biografía (1677-1737)”, Berceo, Revista Riojana de Ciencias Sociales y Humanidades, Instituto de Estudios Riojanos, España, n¹50, 2006, p. 143-168.

Molina Ruiz, Omar, "Magia e Inquisición en el obispado de Michoacán en la segunda mitad del siglo XVIII", Tesis de Licenciatura en Historia, Facultad de Historia, Universidad Michoacana de San Nicolás de Hidalgo, Morelia, 2013.

Montero García, Luis Alberto \& Thiébaut, Virginia, “Cañaverales, trapiches e ingenios en México. Dinámicas históricas y procesos actuales", Revista de Historia, Sociedad y Cultura, México, Universidad Veracruzana, ${ }^{\circ} 23,2014$, p. 11-19.

Montufar, Aurora, "Copal, humo aromático de tradición ritual mesoamericana”, Arqueología Mexicana, México, Editorial Raíces, vol. 23, n¹35, 2015, p. 64-65.

Montufar, Aurora, Los copales mexicanos y la resina sagrada en el Templo Mayor de Tenochtitlán, México, Instituto Nacional de Antropología e Historia, 2007.

Moreno de los Arcos, Roberto, "La Inquisición para indios en la Nueva España (Siglos XVI a XIX)" en Publicaciones Periódicas de la Universidad de Navarra, España, Universidad de Navarra, 1990, p. 1471-1484.

Murillo Velarde, Pedro, Curso de derecho canónico hispano e indiano, México, El Colegio de Michoacán, Universidad Nacional Autónoma de México, 2004.

Olmos, Andrés de, Tratado de hechicerías y sortilegios, México, Universidad Nacional Autónoma de México, 1990.

Russell, Bertrand, Religión y ciencia, México, Fondo de Cultura Económica, 1973.

Sánchez Díaz, Gerardo, "Hechicería y curanderismo entre los nahuas de la Costa y la Tierra Caliente de Michoacán en el siglo XVII", Revista Internacional d'Humanitats, Barcelona, España, Secretaría de Estado de Cultura, año XVIII, n³5, 2015, p. 67-74.

Sánchez Ruíz, Juan Francisco \& Tejeda Rosales, María Elena \& Manuel Guillermo Sánchez Tejeda, "La farmacia, la medicina y la herbolaria en el códice florentino", Revista Médica de Ciencias Farmacéuticas, México, Universidad Nacional Autónoma de México, vol. 43, n³, 2012, p. 55-66.

Scharrer, Beatriz, "Trabajadores y cambios tecnológicos en los ingenios (siglos XVII-XVIII)" en Espriu Artís, Gloria \& Von Mentz, Brígida \& Mohar Betancourt, Luz María \& Suárez Argüello, Clara Elena \& Beatriz Scharrer Tamm, Trabajos y sociedad en la historia de México siglos XVI-XVIII, México, Centro de Investigaciones y Estudios en Antropología Social, 1992, p. 148-186.

Távarez, David, “Ciclos punitivos, economía del castigo y estrategias indígenas ante la extirpación de idolatrías en Oaxaca y México (Nueva España), siglos XVI-XVIII" en Zaballa Beascoechea, Ana de (coord.), Nuevas perspectivas sobre el castigo indígena en la Nueva España siglos XVI-XVIII, País Vasco, Agritalpen Zerbitzua Servicio Editorial, 2005, p. 37-56.

Teja Andrade, Jesús, Tuzantla Tiquicheo Susupuato Juárez. La ruta heroica del oriente michoacano, México, Gobierno del Estado de Michoacán, 1979. 
Traslosheros, Jorge E., "Los indios, la inquisición y los tribunales eclesiásticos en Nueva España, definición jurisdiccional y justo proceso, 1751-c 1750" en Traslosheros, Jorge E. \& Ana de Zaballa Beascoechea (coords.), Los indios ante los foros de justicia religiosa en la Hispanoamérica virreinal, México, Universidad Nacional Autónoma de México, 2010, p. 47-74.

Traslosheros, Jorge, E., "El pecado y el delito. Notas para el estudio de la justicia criminal eclesiástica en la Nueva España del siglo XVII”, Alegatos, México, n58, 2004, p. 368-378.

Traslosheros, Jorge, E., Historia judicial eclesiástica de la Nueva España, México, Universidad Autónoma de México, Editorial Porrúa, 2014.

Valverdu, Jaume, Antropología simbólica. Teoría y etnografía sobre religión, simbolismo y ritual, España, Universitat Oberta Catalunya, 2008.

Zaballa Beascoechea, Ana de, "Del viejo al nuevo mundo: novedades jurisdiccionales en los tribunales eclesiásticos ordinarios en la Nueva España" en Traslosheros, Jorge E. \& Ana de Zaballa Beascoechea (coords.), Los indios ante los foros de justicia religiosa en la Hispanoamérica virreinal, México, Universidad Nacional Autónoma de México, 2010, p. 17-46.

\section{NOTAS}

1. Cagni, Horacio, "Reflexiones en torno a los conceptos de guerra justa y cruzada en su actual revalorización”, Revista enfoques, Chile, vol. VII, n¹0, 2009, p. 157-281. Alfredo Gómez, "Sobre la legitimidad de América: Las Casas y Sepúlveda", Ideas y valores Revista Colombiana de Filosofía, Colombia, vol. 40, n85-86, 1991, p. 3-18. Eduardo Cebreiros Álvarez, "La condición jurídica de los indios y el derecho común: un ejemplo del 'favor protectionis' ”, Panta Rei, Italia, vol. 1, 2004, p. 469-489.

2. Cardozo Cardona, John Jairo, "El desconocimiento del indio y la colonización: entre el mito y la fantasía", Revista Virtual, Colombia, n¹5, 2005, p. 1-15. Caroline Cunill, "El indio miserable: nacimiento de la teoría legal en la América colonial del siglo XVI", Cuadernos Inter.C.A.mbio sobre Centroamérica y el Caribe, Costa Rica, año 8, $\mathrm{n}^{\circ} 9,2012$, p. 233-234.

3. Aguirre Beltrán, Gonzalo, Medicina y magia. El proceso de aculturación en la estructura colonial, México, Instituto Nacional indigenista, 1987, p. 38.

4. Eymeric, Nicolau, Manual del inquisidor, México, Alama Clásicos, 2003, p. 26-66.

5. Greenleaf, Richard E., La inquisición en Nueva España siglo XVI, Fondo de Cultura Económica, 1981, p. 241. Távarez, David, "Ciclos punitivos, economía del castigo y estrategias indígenas ante la extirpación de idolatrías en Oaxaca y México (Nueva España), siglos XVI-XVIII" en Zaballa Beascoechea, Ana de (coord.), Nuevas perspectivas sobre el castigo indígena en la Nueva España siglos XVI-XVIII, País Vasco, Agritalpen Zerbitzua Servicio Editorial, 2005, p. 18-21.

6. Traslosheros, Jorge E., "Los indios, la inquisición y los tribunales eclesiásticos en Nueva España, definición jurisdiccional y justo proceso, 1751-c 1750” en Traslosheros, Jorge E., \& Zaballa Beascoechea, Ana de (coords.), Los indios ante los foros de justicia religiosa en la Hispanoamérica virreinal, México, Universidad Nacional Autónoma de México, 2010, p. 57-66.

7. Murillo Velarde, Pedro, "Libro I, Título II, del foro o fuero competente" en Curso de derecho canónico hispano e indiano, México, El Colegio de Michoacán, Universidad Nacional Autónoma de México, 2004, p. 47. Traslosheros, Jorge E., Historia judicial eclesiástica de la Nueva España, México, Editorial Porrúa, Universidad Nacional Autónoma de México, Instituto de Investigaciones Históricas, 2014, p. 75.

8. El actor es aquel que denuncia. El reo quien es el denunciado y durante la etapa del juicio, se le ponía preso para asegurar que no escapara de la justicia. López Melero, Monserrat, Evolución y 
sistemas penitenciarios y de la ejecución penal, España, Anuario de la Facultad, Universidad de Alcalá, $\mathrm{n}^{\circ}$ 5, 2012, p. 401 y 404.

9. Las cursivas son del texto original. Murillo Velarde, P.," Libro II, Título I de los juicios" en Curso de derecho, Op. Cit., p. 28-29.

10. Murillo Velarde, P., "Libro II, Título I de los juicios" en Curso de derecho, Op. Cit., p. 39.

11. Olmos, Andrés de, Tratado de hechicerías y sortilegios, México, Universidad Nacional Autónoma de México, 1990, p. 77. Gruzinski, Serge \& Carmen Bernand, De la idolatría una arqueología de las ciencias religiosas, México, Fondo de Cultura Económica, 1992, p. 226.

12. Murillo Velarde, P., "Libro 1, Título XXXI del oficio del juez ordinario" en Curso de derecho, Op. Cit., p. 397.

13. "De las injurias y el daño hecho", consúltese en Rivera, Mariano, III Concilio Provincial Mexicano, celebrado en México en el año de 1585, confirmado en Roma por el Papa Sixto V, y mandado a observar por el gobierno español en diversas reales Órdenes, México, 1569, Libro V, Título VIII, Capítulo II, p. 380-381.

14. Murillo Velarde, P., "Libro 1, Título IV de la costumbre" en Curso de derecho, Op. Cit., p. 284. Murillo Velarde, P., "Libro 1, Título XXXIX del oficio del juez ordinario" en Curso de derecho, Op. Cit., p. 404.

15. Ciruelo, Pedro, Reprobación de las supersticiones y hechicerías, España, Maxtor, 2005, p. 1-147.

16. Murillo Velarde, P., "Libro 1, Título XXXIX del oficio del juez ordinario", en Curso de derecho, Op. Cit., p. 405.

17. Moreno de los Arcos, Roberto, "La Inquisición para indios en la Nueva España (siglos XVI a XIX)" en Publicaciones Periódicas de la Universidad de Navarra, España, Universidad de Navarra, 1990, p. 1483.

18. Hay recordar que uno de los métodos para tener un control y conocimiento de la feligresía fueron las confesiones, en este sacramento como hemos mencionado encontramos dos tipos de significados; que los indios acudieran a recibir este derecho religioso reafirmaba la idea humanista que en efecto los naturales tenían alma, y en otro término, los libros de confesión le sirvieron a los párrocos para conocer qué tipo de feligreses tenían cada partido u obispado, asimismo, cuáles eran los pecados más comunes, inclusive conocer si existían rencillas con otros habitantes del mismo partido. Por otro lado, a la creación de los Tribunales Ordinarios se da autoridad a los eclesiásticos para atender las causas religiosas dejando al rey a cargo de las causas civiles Martínez Ferrer, Luis, "Las Órdenes mendicantes y el sacramento de la confesión en Nueva España (siglo XVI)”, Revista Complutense de Historia de América, Madrid, n48, 1998, p. 50-57. Murillo Velarde, P., "Libro I, Título XXXII del oficio del juez", en Curso de derecho, Op. Cit., p. 345. Moreno de los Arcos, R., La Inquisición para indios, Op. Cit., p. 1483.

19. Eymeric, N., Manual del inquisidor, Op. Cit., p. 27-67

20. "De los hechiceros", Galván Rivera, M., III Concilio Provincial, Op. Cit., Libro V, Título V, Capítulo I, p. 374-375.

21. "De los hechiceros", Galván Rivera, M., III Concilio Provincial, Op. Cit., Libro V, Título V, Capítulo I, p. 374-375.

22. Russell, Bertrand, Religión y ciencia, México, Fondo de Cultura Económica, 1973, p. 59-68

23. Para ahondar más sobre la jurisdicción ordinaria y la concepción del pecado y crimen véase: Traslosheros, Jorge, E., "El pecado y el delito. Notas para el estudio de la justicia criminal eclesiástica en la Nueva España del siglo XVII”, Alegatos, México, n58, 2004, p. 369.

24. Murillo Velarde, P., "Libro V, Título XXI de los sortilegios" en Curso de derecho, Op. Cit., p. 189. 25. Murillo Velarde, P., "Libro V, Título XXI de los sortilegios" en Curso de derecho, Op. Cit., p. 191.

26. Bajo la percepción que Michel Foucault describe en Vigilar y castigar se puede definir el castigo como la parte más oculta del proceso penal, el castigo corporal es un modo de corregir las faltas o delitos, un proceso para recibir el perdón, puesto que, en el sistema punitivo se puede separar en dos vertientes, la primera castigar el cuerpo en la tierra, y la segunda mortificar el alma para que 
no vaya al infierno. Para el caso de los naturales el castigo significó un método por el cual se podía purgar al indio de los pecados y de esta forma se cuidaba de su alma. Foucault, Michel, Vigilar y castigar, México, Siglo XXI Editores, 2014, p. 18-36. "Los obispos y los gobernadores reales protejan a los indios”, Galván Rivera, M., III Concilio Provincial, Op. Cit., Libro V, Título VIII, Capítulo II, p. 210.

27. Traslosheros, Jorge E., Iglesia, Justicia y sociedad en la Nueva España, México, Editorial Porrúa, Universidad Iberoamericana, México, 2004, p. 91

28. Cortés Máximo, Juan Carlos, De repúblicas de indios a ayuntamientos constitucionales: pueblos sujetos y cabeceras de Michoacán, 1710-1831, México, Instituto de Investigaciones Históricas, Universidad Michoacana de San Nicolás de Hidalgo, 2012, p. 41.

29. Coli Hurtado, Atlántida \& Sánchez Salazar, María Teresa, "La minería en el obispado de Michoacán a mediados del siglo XVIII”, en Investigaciones Geográficas, México, Universidad Nacional Autónoma de México, Boletín 39, 1999, p. 109.

30. Teja Andrade, Jesús, Tuzantla Tiquicheo Susupuato Juárez. La ruta heroica del oriente michoacano, México, Gobierno del Estado de Michoacán, 1979, p. 18.

31. Guzmán Pérez, Moisés, "La conquista y la dominación española”, en Tuzantla historia en la tierra caliente, México, Ayuntamiento Constitucional de Tuzantla, 1991, p. 39-36. Teja Andrade, J., Tuzantla Tiquicheo Susupuato, Op. Cit., p. 9-37.

32. La actividad agrícola como lo es en este caso relacionado a los trapiches azucareros propició entonces que esos "círculos cerrados" o actividades semi-clandestinas dieran apertura a la difusión de los conjuros mágicos, o recetas mágicas que permitieran obtener lo deseado, a su vez, dar noticia sobre algún hechicero o curandero cercano a la región. Aguilar Rivera, Noé, "La caña de azúcar y sus derivados en la Huasteca San Luis Potosí México", Diálogos Revista Electrónica de Historia, San José, vol. 17, n¹, 2010, p. 86-88. Montero García, Luis Alberto \& Thiébaut, Virginia, "Cañaverales, trapiches e ingenios en México. Dinámicas históricas y procesos actuales", Revista de Historia, Sociedad y Cultura, México, n²3, 2014, p. 11. López Pereda, Martha, "Superstición, brujería y esclavitud en una sociedad colonial: Nueva España a mediados del siglo XVIII”, Tesis de Maestría en Historia, Facultad de Filosofía y Letras, Universidad de Cantabria, Cantabria, España, 2014, p. 13. Scharrer, Beatriz, "Trabajadores y cambios tecnológicos en los ingenios (siglos XVIIXVIII", en Espriu Artís Gloria \& Von Mentz, Brígida \& Mohar Betancourt, Luz María \& Suárez Argüello, Clara Elena \& Scharrer Tamm, Beatriz, Trabajos y sociedad en la historia de México siglos XVI-XVIII, México, Centro de Investigaciones y Estudios en Antropología Social, 1992, p. 162-180.

33. Archivo Histórico de la Casa Natal de Morelos (en adelante AHCNM), Fondo diocesano (Fondo Diocesano), Justicia (J), Procesos Criminales (PC), Hechicería (H), Caja 834 (C), Expediente 1 (E), Causa criminal que se siguió en contra de Juan Rosales, acusado ante el juez del partido de Tuzantla por practicar la hechicería, 22 de febrero de 1732, Foja (fs) 1.

34. AHCNM, Fondo Diocesano, J, PC, H, C, 834, E, 1, fs. 1 y 2.

35. AHCNM, Fondo Diocesano, J, PC, H, C, 834, E, 1, fs, 2.

36. AHCNM, Fondo Diocesano, J, PC, H, C, 834, E, 1, fs, 3.

37. AHCNM, Fondo Diocesano, J, PC, H, C, 834, E, 1, fs. 3.

38. AHCNM, Fondo Diocesano, J, PC, H, C, 834, E, 1, fs, 4.

39. Murillo Velarde, P., "Libro V, Título I, de las acusaciones, inquisiciones y denuncias", en Curso de derecho, Op. Cit., p 30.

40. Traslosheros, J., E., Historia judicial, Op. Cit., p. 66-95.

41. Murillo Velarde, P., "Libro II, Título III de la presentación del libelo", en Curso de derecho, Op. Cit., p. 63.

42. En los juicios se negaba dar testimonio a personas catalogadas como infantes, locos, ebrios, dementes por falta de fe y fama, lictores, verdugos. A las personas pobres sólo se les permitía dar testimonio si se les catalogaba como honestas. Para más información véase: Murillo Velarde, P., Libro II, Título XX “De los testigos y sus declaraciones”, en Curso de derecho, Op. Cit., p. 141-149. 
43. Murillo Velarde, P., "Libro II, Título XX de los testigos y sus declaraciones", en Curso de derecho, Op. Cit., p. 63-64.

44. El Protomedicato se fundó en el año de 1630 sin embargo las actividades de cuidar el oficio médico se observan desde el siglo XVI cuando en el año de 1527 se nombra como primer protomédico a Don Pedro López con la finalidad de examinar a los herbolarios, ensalmadores y especieros, para más información véase: González Lozano, María del Carmen \& Almeida López, María Guadalupe, "El Protomedicato", en Soberanes Fernández, José Luis, Memoria del III Congreso de Historia del Derecho Mexicano (1983), México, Universidad Nacional Autónoma de México, 1984, p. 314.

45. Limón Olvera, Silvia, El fuego sagrado, simbolismo y ritualidad, entre los nahuas, México, Universidad Nacional Autónoma de México, 2012, p. 60-65.

46. Linares E., \& Bye R., "El copal en México”, Biodiversitas, México, n78, 2008, p. 8. Sánchez Ruíz, Juan Francisco \& Tejeda Rosales, María Elena \& Sánchez Tejeda, Manuel Guillermo, "La farmacia, la medicina y la herbolaria en el códice florentino", Revista Médica de Ciencias Farmacéuticas, México, vol. 43, n³, 2012, p. 59.

47. Chazado Basañez, Miguel \& Mostul, Brun L. \& García Lara, Feliciano, "Los copales mexicanos", Bouteloua, Revista científica internacional dedicada al estudio de la flora ornamental, España, vol. 7, 2011, p. 59.

48. Montufar, Aurora, Los copales mexicanos y la resina sagrada en el Templo Mayor de Tenochtitlán, México, Instituto Nacional de Antropología e Historia, 2007, p. 7, 15 y 68. Montufar, Aurora, "Copal, humo aromático de tradición ritual mesoamericana", Arqueología Mexicana, México, Editorial Raíces, vol. 23, n¹35, 2015, p. 64-65.

49. García Martínez, Luz Elena, "Aspectos socio-ecológicos para el manejo sustentable del copal en el ejido de Acateyahulco, Gro.", Tesis de Licenciatura en Ciencias Ambientales, Centro de Investigaciones en Ecosistemas, Universidad Nacional Autónoma de México, México, 2012, p. 11-32. Hernández Hernández, Adalberta Alejandrina \& López Santiago, María del Carmen \& Méndez Hernández, Ángeles \& Morales López, Jael, Herbolaria oaxaqueña para la salud, México, Instituto Nacional de las Mujeres, 2009, p. 99-100.

50. Montufar, A., Los copales mexicanos, Op. Cit., p. 46.

51. Se sabe que en la Nueva España circulaban famosos escritos que orientaban a las personas sobre las plegarias adecuadas para sanar determinados males. Véase: Chávez Guzmán, Mónica, "Médicos y medicinas en el mundo peninsular maya colonial y decimonónico", Península, Mérida, vol. VI, n², 2011, p. 79.

52. AHCNM, Fondo Diocesano, J, PC, H, C, 834, E, 1, fs 1-2.Campos Moreno, Araceli, "Textos mágicos del Archivo Inquisitorial de la Nueva España”, Literatura Mexicana, México, vol. 5, n¹, 1994, p. 173-174. López Pereda, M., Superstición, brujería y esclavitud, Op. Cit., p. 23-37. Sánchez Díaz, Gerardo, "Hechicería y curanderismo entre los nahuas de la Costa y la Tierra Caliente de Michoacán en el siglo XVII", Revista Internacional d'Humanitats, Barcelona, año XVIII, n³5, 2015, p. 68. Valverdu, Jaume, Antropología simbólica. Teoría y etnografía sobre religión, simbolismo y ritual, España, Universitat Oberta Catalunya, 2008, p. 161-170.

53. Campos Moreno, A., Textos mágicos del Archivo, Op. Cit., p. 173-174.

54. Alberro, Solange, Inquisición y sociedad en México 1571-1700, México, Fondo de Cultura Económica, 1988, p. 71. Zaballa Beascoechea, Ana de, "Del viejo al nuevo mundo: novedades jurisdiccionales en los tribunales eclesiásticos ordinarios en la Nueva España" en Traslosheros, Jorge E. \& Zaballa Beascoechea, Ana de (coords.), Los indios ante los foros de justicia religiosa en la Hispanoamérica virreinal, México, Universidad Nacional Autónoma de México, 2010, p. 28-41.

55. AHCNM, Fondo Diocesano, J, PC, H, C, 834, E, 1, fs 4 y 5.

56. Gargallo García, Oliva, La comisaría inquisitorial de Valladolid de Michoacán, México, Universidad Michoacana de San Nicolás de Hidalgo-Instituto de Investigaciones Históricas, 1999, p. 25-26. Molina Ruiz, Omar, "Magia e Inquisición en el obispado de Michoacán en la segunda mitad del 
siglo XVIII", Tesis de Licenciatura en Historia, Facultad de Historia, Universidad Michoacana de San Nicolás de Hidalgo, Morelia, 2013, p. 51. Zaballa Beascoechea, A., "Del viejo al Nuevo Mundo", Op. Cit., p. 38-39.

57. García de Verón, María Esther, "El cabildo de Córdoba ante el Tribunal del Protomedicato de Buenos Aires", ponencia presentada en XI Congreso del Instituto de Historia del Derecho Indiano, Buenos Aires, 4-9 de septiembre, 1995, p. 4 y López Pereda, M., "Superstición, brujería y esclavitud", Op. Cit., p. 23 y 24.

58. Báez Cubero, Lourdes, "El uso del ritual de la 'santa Rosa' entre los otomíes orientales de Hidalgo: el caso de Santa Ana Hueytlalpan”, Cuicuilco, México, vol. 19, n 53, 2012, p. 158-167.

59. Balderas Sánchez, Norma, "La herbolaria en la Nueva España y su empleo en la botica del Colegio de Vizcaínas 1775-1780”, Multidisciplina, México, n¹1, 2012, p. 49, y López Pereda, M., "Superstición, brujería y esclavitud", Op. Cit., p. 33 y 33.

60. Los castigos para indios estipulados en el III Concilio Provincial dependía de su situación, si los naturales tenían bienes serían confiscados, sin embargo, era muy raro debido a su personalidad jurídica que éstos tuvieran cierta capacidad económica por lo cual eran comunes los azotes y el encarcelamiento, véase: "De los hechiceros", Galván Rivera, Mariano, III Concilio Provincial, Op. Cit., Libro V, Título V, Capítulo I, p. 374 y 375. \& Murillo Velarde, P., "Libro I, Título IV de la costumbre", en Curso de derecho, Op. Cit., p, 284, y "Libro 1, Título XXXIX del oficio del juez ordinario" en Op. Cit., p. 404.

61. AHCNM, Fondo Diocesano, J, PC, H, C, 834, E, 1, fs 7.

62. Murillo Velarde, P., "Libro II, Título I de los juicios y Título XXVII de la sentencia y de la cosa juzgada" en Curso de derecho, Op. Cit., p. 41 y 240.

\section{RESÚMENES}

En el presente trabajo examinaremos un juicio contra un indio acusado de hechicero en el partido de Tuzantla, perteneciente al obispado de Michoacán en el año de 1732. Comenzamos analizando la protección otorgada a los indios, según las categorías jurídicas a las cuales estaban sujetos, y continuamos identificando qué tipo castigos se les permitía aplicar. Para conocer la condición jurídica de los naturales nos adentraremos en la función de los jueces y examinamos la protección paternalista hacia los indios a la hora de un juicio. Finalmente, analizamos cómo se representó el sincretismo religioso en un juicio eclesiástico y cuál fue la postura del juez y del reo.

This work examines a trial against an Indian accused of sorcery in the Tuzantla district, in the bishopric of Michoacán in 1732. We begin by analysing the protection granted to Indians based on the legal categories to which they were subjected, and we identify the type of punishment that they could receive. Then, to understand the legal status of Indians, we focus on the role of judges and the paternalistic protection they were meant to display in trials against Indians. Finally, we analyse the representation of religious syncretism in this ecclesiastical trial, as well as the judge's and the culprit's interventions.

Ce travail examine un procès contre un indien accusé de sorcellerie dans le district de Tuzantla, qui appartient à l'évêché de Michoacán, en 1732. Nous commencerons par analyser la protection octroyée aux Indiens, d'après les catégories juridiques dont ils relevaient, puis nous identifierons 
le type de peines que l'on pouvait leur appliquer. Afin de connaître la condition juridique des Indiens, nous nous centrerons sur la fonction des juges et sur la protection paternaliste envers les Indiens à l'heure de les juger. Enfin, nous analyserons comment était représenté le syncrétisme religieux dans un jugement ecclésiastique, ainsi que l'intervention du juge et de l'accusé.

ÍNDICE

Keywords: New Spain, 18th Century, Justice, Sorcery, Healers

Mots-clés: Nouvelle Espagne, XVIIIe siècle, justice, sorcellerie, guérisseur

Palabras claves: Nueva España, siglo XVIII, justicia, hechicería, curanderismo

\section{AUTOR}

\section{QUETZALCOATL TONATIUH URIBE SÁNCHEZ}

Licenciado en Historia y estudiante de la Maestría en Historia, Universidad Michoacana de San Nicolás de Hidalgo, México. thesaenz[at]outlook.com

El texto es resultado de la Tesis de Licenciatura del autor.. 